\title{
CORRESPONDENCE
}

\section{To the Editor of the Journal of the Royal Aëronautical Society.}

Sik, - The notable addition to the Society's library of a selection of rare and interesting books relating to early phases of aeronautics (as described in the article reprinted in last month's Journal from the "Times " Literary Supplement) is rightly regarded as a matter of congratulation. May I be allowed, as one greatly interested in aeronautical history, to offer a few observations on the two-fold interest of this acqulsition?

Firstly, it may be claimed that the purchase of these books for the Society's library is of consequence, inasmuch as it tends to make the library--what it surely ought to become-the most important collection of historical and technical books, English and foreign, in all branches of that science which it is the aim of the Society to further by every means in its power. If it be said-as one has heard it said of collections of early works on other sciences-that the older books are scldom relerred to, it may be answered that the prestige of any scientific institution receives permanent support from the possession of an important and wellarranged library of reference. The acquisition for the library of the Institution of Electrical Engineers of the remarkable collection of rare early works on electricity and magnetism, formed by the late Professor Sylvanus Thompson, may be cited as a signal example.

Secondly, the possession of a library of great and increasing historical value may well prove to be a matter of more direct practical importance, should it lead the Society to encourage a study of the historical aspects of aeronautical history. Hitherto, very little serious work of that character has been done in England-the publication by the Society of the series of "Aeronautical Classics" is hardly more than an admirable exception which goes to prove the rule. Encouragement is at the present time the more desirable in view of the marked attention which has been paid in recent years to the study of historical science and technology in all directions. Important work of this kind has been done, and is now being done, in England-examples will readily occur to all students of science-and it is therefore unnecessary to particularise. The remark holds good of the Continent, and in the United States there has been remarkable activity on similar lines of historical research, covering the more important fields of applied science and technical industries. Aeronautical science, though the youngest regarded from the point of view of practical achievement, is destined for years to come to be in the van of progress. Can it afford to stand apart from the endeavours now being made to satisfy the need for historical knowledge of a technical character by neglecting the study of its own history-a history which, though scant in important material, and interminably slow in the tale of its unfolding, is yet of undeniable interest, and should be allowed its rightful place in the annals of science and engineering?

Up to the present, however, it must be admitted that in England scholarship has almost wholly ignored, or at the least shown a marked indifference to, the historical aspects of aeronautics. It is significant that to this day Hatton Iurnor's cumbrous and ill-arranged compilation, "Astra Castra" (published in 1865), is perforce still frequently referred to as the "best" and "fullest" authority. That it has been quoted by countless writers may be fully admitted, but it is difficult to believe that those who cite it so freely (though not always by name) ever studied the subject at first hand. As a matter of fact, there is very little original work in Turnor's rolume-of the 518 pages, about $35^{\circ}$ consist of tedious padding in the form of poetical and Scriptural quotations, or wholesale 
reprints of earlier books and essays, made for the most part without any comment or connected narrative. Further, it contains a full measure of inaccuracies and notable omissions, and a bibliography which is hopelessly inadequate.

Moreover-not to attempt a survey of aeronautical literature-the D.N.B., though it includes such well-known pioneers of the frce balloon as Vincenzo Lunardi (who rightly described himself as a cr"id of Britain only by a species of adoption), Charles Green, George Gale (whose inclusion it would be hard to justify), and Henry. Coxwell, omits such important names in the evolution of British aeronautical science as. Sir George Coyley (the full extent of whose work in both branches of aeronautics-dirigible balloons and mechanical flight-has not yet been adequately noticed), John Stringfellow, F. H. Wenham and Percy S. Pilcher. Indeed, it must be said that English aeronautical books dealing with the historical aspects are, broadly speaking, unscholarly, compiled with a minimum of research, unreliable as to facts, and usually lacking in authorities, while they fail to convey any large view of the lines on which aeronautical science cvolved.

On the other hand, France has been far better served by her scholars and scientists. Faujas de Saint-Fond set an example as early as 1783 in his scientific account of the first aerostatic achievements, an example followed in later times by Dupuis-Delcourt, Landelle, Tissandier (whose fine "Histoire des Ballons" is, however, marred by too frequent errors), Lecornu, and others, all of whose writings are distinctly in advance of any similar works published in England. Nor can we boast anything to compare with the sumptuously illustrated volumes - designed as pictorial histories of flight-published in Paris under the editorship of M. F.-L. Bruel (1909) and the Comte de la Vaux (1922), or with the comprehensive and accurate I.L.A. Catalogue compiled by Dr. Liebmann and Dr. Wahl in connection with the Aeronautical Exhibition at Frankfort in 1909. Italy, also, has to her credit the scholarly historical monograph "Il Volo in Italia" by Guiseppe Boffito, published in Florence two years ago, while a more modest but useful little work by E. Fuld was privately printed at Amsterdam in I918 under the title of "Uit de eerste jaren der Luchtvaart in Nederland."

In face of these facts-capable of amplification, but of themselves surely not creditable to a country which has done great things in the air, or to an Empire which must ever be as deeply corcerned in aerial as it is in maritime navigation-may I respectfully urge the Council of the Society to encourage, if they cannot actively promote, researches into the history of aeronautical science, to which the admirable acquisition herein discussed may be deemed to serve as a fitting prelude. Would it, for instance be possible to afford a brief space in the pages of the Journal for limited excursions into the technology of aeronautics? Or if the regrettably high cost of printing precludes even occasional essays in that direction-and it will be generally allowed that the invaluable papers recording the most recent results of aeronautical research, as printed in the Journal from month to month, constitute a very important part of the Society's workmight it not exert some influence by inviting the co-operation of the Newcomen Society (whose excellent work on the history of engineering and technology is deserving of all possible support) in discussions on subjects of aeronautical interest? As a lay member of both Societies I throw out these ideas unofficially and with all diffidence, but not without hope of some result.

And may it not be added there is reason to believe that endeavours on the lines. above mentioned would tend to have the incidental but most desirable result of stimulating public interest in aeronautical matters at large? One's limited experience in lecturing on historical aeronautics confirms the impression that in this, as in other matters, the regrettable lack of interest is due, partly at least, to lack of knowledge.- Yours faithfully,

Bromley.

J. E. Hodgson.

March I2th, 1923 . 